\title{
Alterations of Membrane Phosphorylation in Erythrocyte Membranes from Patients with Duchenne Muscular Dystrophy
}

\author{
J. D. VICKERS, A.J. MCCOMAS, AND M.P. RATHBONE
}

SUMMARY: The phosphorylation of spectrin, band 3 protein, and the phospholipids of erithrocite membranes (ghosts) was examined in 10 patients with Duchenne muscular dystrophy (DMD) and in healthy age- and sex-matched controls. The rates of phosphorylation of spectrin and band 3 protein were significantly higher in ghosts prepared from patient blood than from control blood at both $30^{\circ} \mathrm{C}$ and $37^{\circ} \mathrm{C}$. However, the mean increases in the rate of phosphorylation of

RESUME: La phosphorylation de la spectrine, de la protéine de la 3ième bande. el des phospholipides des membranes érythroclvaires furent étudiés chez 10 patients souffrant de dystrophie musculaire de Duchenne (DMD) et chez des contrôles normaux apparillés pour âge et sexe. Le taux de phosphorylation de la spectrine et de la protéine de la 3ième bande étaient significativement plus hauts dans les membranes des patients que celles des contrôles, et ce à $30^{\circ} \mathrm{C}$ ou $37^{\circ} \mathrm{C}$. Cependant l'augmentation dans le taux de phosphorylation en réponse à un change- both spectrin and band 3 protein in response to a temperature change from $30^{\circ} \mathrm{C}$ to $37^{\circ} \mathrm{C}$ were identical in ghosts from patient and controls. Phosphorylation of phospholipid and its temperature response did not differ between patients and controls. These results complement previous observations of differences in erythrocytes from patients with $D M D$. The similarity of the changes in phosphorylation of both spectrin and band 3 protein indicates a common cause. possibly their lipid emironment.

ment de température de $30^{\circ} \mathrm{C}$ à $37^{\circ} \mathrm{C}$ était identique dans les membranes des deux groupes. La phosphorylation des phospholipides el sa réponse à la température ne différaient pas entre les deux groupes. Ces résultats confirment les différences préalablement notées dans les érythrocytes provenant de patients souffrant de DMD. La similarité des modifications de la phosphorylation de la spectrine et de la protéine de la Bième bande indique une cause commune, probablement lenvironnement lipidique.

\section{INTRODUCTION}

Although Duchenne muscular dystrophy (DMD) has long been considered a primary myopathy, recently there have been reports of alterations in extramuscular tissues such as motoneurons (McComas et al., 1971) and the vascular supply to the muscles (Engel, 1974) in patients with this disease. Considerable attention has also focused upon reported alterations in muscle and erythrocyte membranes from patients with DMD. For example, the stimulation of sarcolemmal adenylate cyclase by epinephrine or sodium fluoride is reduced both in fresh muscle (Mawatari et al., 1974) and cultured muscle (Mawatari et al., 1976) while the sarcolemmal $\mathrm{Mg}^{2+}$ ATPase and $\mathrm{Ca}^{2}$ ATPase have increased activities (Dhalla et al., 1973). Since erythrocyte membranes show similar alterations and are more easily obtained than sarcolemma, they have been more extensively studied. Differences have been reported in the lipid composition of erythrocyte membranes (Kunze et al., 1973; Howland and lyer, 1977; Kalofoutis et al., 1977), in erythrocyte membrane deformability (Percy and Miller, 1975; Missirlis et al., 1977), in membrane protein conformation and/or organization (Butterfield, 1977), and in ion transport (Sha'afi et al., 1975). Furthermore, the activities of membrane-bound enzymes such as the $\left(\mathrm{Na}^{+}+\mathrm{K}^{+}\right) \mathrm{Mg}^{2+}$ ATPase (Brown et al., 1967; Peter et al., 1969; Mawatari et al., 1976; Niebroj-Dobosz, 1976), the $\mathrm{Ca}^{2^{+}} / \mathrm{Mg}^{2^{+}}$ATPase (Hodson and Pleasure, 1977), and phospholipase A (lyer et al., 1976) are abnormal in patients with DMD. The activities of the endogenous membrane protein kinases (PKase) that phosphorylate
From the MRC Group in Developmental Neurobiology, Department of Neurosciences, McMaster University Medical Centre, Hamitton, Ontario. Canada.

Reprint requests to: Dr. .Iohn D. Vickers, McMaster University. Dept. of Neuroscience, 1200 Main St. W.. Hamilton, Ontario, Canada L8S 4.19 
spectrin and band 3 protein have also been shown to be elevated in both patients and carriers of DMD (Appel and Roses, 1976; Roses and Appel, 1976; Roses et al., 1975, 1976a).

Abtreviations SDS-PAGE: sodium dodecly sulphate-polyacrylamide gel electrophoresis. PKase: protein kinase. ATP: adenosine triphosphate. DMD: Duchenne muscular dystrophy.

The lipids of erythrocyte membranes contribute little to the deformability of the membranes compared to the protein components (Evans, 1973). However, even small alterations in lipid composition of membranes alter the activity of many membrane-bound enzymes (Farias et al., 1973; Coleman, 1973; De Kruyff et al., 1973; Puchwein et al., 1974; Warren et al., 1975). In particular, the activity of the membrane-bound protein kinase is sensitive to changes in membrane lipid composition (Vickers and Rathbone, 1977). Therefore, alterations in the lipid composition of the erythrocyte membranes from DMD patients may be responsible for the changes in the activity of several membrane enzymes, including the protein kinase which phosphorylates spectrin. Since spectrin is a major component of the sub-membrane network and its role in the network is affected by the extent of its phosphorylation (Sheetz and Singer, 1977; Birchmeier and Singer, 1977; Hosey and Tao, 1977; Pinder et al., 1977), the change in spectrin phosphorylation could mediate the effect of a lipid change upon the mechanical properties (deformability) of the membrane. Alternatively, it has been proposed that the spectrin substrate of the protein kinase is itself abnormal in patients with DMD (Roses et al., 1976b). Therefore, although several explanations are possible for the increased spectrin phosphorylation, it is probable that spectrin phosphorylation affects membrane deformability (Hosey and Tao, 1977).

To study the causes of the erythrocyte alterations further, we have examined the protein kinase activity that phosphorylates spectrin in erythrocyte ghost membranes from DMD patients and age- and sexmatched controls. We have compared it with the phosphorylation of band 3 protein and phospholipids. Since their membane lipid environment influences the response of the activities of many membrane-bound enzymes to temperature change (Raison et al., 1971; Kumamoto et al., 1971; Kreiner et al., 1973; De Kruyff et al,, 1973; Kimelberg, 1975; Hesketh et al., 1976) we have assayed these enzymes at $30^{\circ} \mathrm{C}$ and at $37^{\circ} \mathrm{C}$ to examine their temperature response.

\section{MATERIALS AND METHODS}

$\left[\gamma^{32} \mathrm{P}\right] \mathrm{ATP}$ (Specific activity $>10$ $\mathrm{Ci} / \mathrm{mmole}$ ) was obtained from New England Nuclear Canada (Dorval, Quebec) and diluted to a specific activity of approximately $2 \mathrm{Ci} /$ mmole with unlabelled ATP from the Sigma Chemical Co. (St. Louis, Missouri). Chemicals for SDS-PAGE were obtained from the BioRad Corporation (Mississauga, Ontario), except the Amido Black 10B which was obtained from Canlab (Toronto, Ontario).

Patients studied fulfilled the clinical criteria for the disease (McComas, 1977). Blood was collected from a forearm vein of healthy donors and patients and mixed with acid citrate dextrose anticoagulant (1 part anticoagulant to 6 parts whole blood (Aster and Jandl, 1964) by the staff of Clinical Neurosciences, coded and immediately analyzed blind for PKase activity. The code was broken only when the entire series of patients was completed.

Red blood cells were washed and converted to ghosts as described by Fairbanks et al. (1971). PKase activity was determined immediately after preparation of ghosts. Approximately $75 \mu \mathrm{g}$ of ghost were incubated in a $100 \mu 1$ incubation mixture containing $5 \mu \mathrm{M}\left[\gamma^{32} \mathrm{P}\right]$ ATP, $20 \mathrm{mM} \mathrm{MgCl}_{2}$, $0.005 \%$ saponin and $20 \mathrm{~m} \mathrm{M}$ Imidazole$\mathrm{HCL}$ buffer $\mathrm{pH} 7.4$ for $5 \mathrm{~min}$. at $30^{\circ} \mathrm{C}$ or $37^{\circ} \mathrm{C}\left( \pm 0.3^{\circ} \mathrm{C}\right)$. The reaction was terminated by addition of $10 \mu \mathrm{l}$ of $11 \%$ SDS solution containing $5 \mathrm{mM}$ EDTA and $6 \mathrm{mM}$ 2-mercaptoethanol and cooling on ice after which $10 \mu 1$ of $50 \%$ sucrose and $2.5 \mu \mathrm{l}$ of pyronin $Y$ $(1 \mathrm{mg} / \mathrm{ml})$ were added. A $100 \mu \mathrm{l}$ portion of this mixture was fractionated on SDS-PAGE gels $(6 \%$ acrylamide) prepared as described by
Weber and Osborne (1969). The gels were then stained with Amido Black $10 \mathrm{~B}$ in $7.5 \%$ acetic acid $(\mathrm{v} / \mathrm{v})$, destained in $7.5 \%$ acetic acid, and the label incorporated into portions of gel containing spectrin, band 3 protein and phospholipid determined by counting Cerenkov radiation in a Beckman scintillation counter. Phospholipid was identified as the peak of label immediately behind the tracking dye (Avruch and Fairbanks, 1974). Gel destaining was sufficient to remove any unreacted [ $\gamma^{32}$ P]ATP and free [32P] phosphate from the gels. Radioactive decay was accounted for by counting samples of the [ $\left.\gamma^{32} \mathrm{P}\right]$ ATP solution used for each assay (which contained a known amount of ATP) at the same time as the experimental samples. Kinase activity was expressed as pmoles of [32P] phosphate incorporated per minute of incubation per $\mathrm{mg}$ of ghost protein (abbreviated pmole $/ \mathrm{min} / \mathrm{mg}$ in text).

Membrane cholesterol and total phosphate were determined on 2propanol extracts of ghosts $(50 \mu)$ of ghost in $950 \mu$ l of 2-propanol) as described previously (Stewart et al., 1977). Protein was determined by the method of Lowry et al. (1951). Statistical analyses were done by the student's t-test for paired samples since the PKase assays of each patient sample and its age-and sex-matched control were performed together (Runyon and Haber, 1972) and by linear regression analysis (Edwards, 1976).

\section{RESULTS}

Preliminary studies of erythrocyte ghost PKase activities indicated that using an incubation mixture described by Avruch and Fairbanks (1974) resulted in higher activities for both the spectrin and band 3 protein kinases at $25^{\circ} \mathrm{C}$ than the incubation mixture used by Roses et al. (1975). Increasing the incubation temperature further increased the activities. However, the increased rate of the phosphorylations due to the $\mathrm{pH}$ and temperature changes did not result in earlier reduction in the reaction velocities, and the reactions were essentially linear up to 5 minutes of incubation. We have thus used these more 
favourable conditions with a 5 minute incubation period for determination of PKase activities in this study.

\section{PROTEIN KINASE ACTIVITY}

The phosphorylation of both spectrin and band 3 protein was greater in patients* than in controls at both temperatures studied (Figure 1). The rate of spectrin phosphorylation of patient ghosts was $10.25 \pm 0.36$ $\mathrm{pmole} / \mathrm{min} / \mathrm{mg}$ and $15.94 \pm 0.48$ $\mathrm{pmole} / \mathrm{min} / \mathrm{mg}$ at $30^{\circ} \mathrm{C}$ and $37^{\circ} \mathrm{C}$ respectively compared to $9.01 \pm 0.40$ $\mathrm{pmole} / \mathrm{min} / \mathrm{mg}$ and $14.02 \pm 0.70$ $\mathrm{pmole} / \mathrm{min} / \mathrm{mg}$ for the control ghosts. The differences were significant at both $30^{\circ} \mathrm{C}$ and $37^{\circ} \mathrm{C}(\mathrm{p}<0.01$ and $\mathrm{p}<0.05$ respectively). The PKase activities of ghosts from patients were increased identically to $114 \pm 5.7 \%$ of the activities of control ghosts at both temperatures.

The rate of phosphorylation of the band 3 protein was $4.19 \pm 0.17$ pmole/ $\mathrm{min} / \mathrm{mg}$ and $6.51 \pm 0.22 \mathrm{pmole} / \mathrm{min} /$ $\mathrm{mg}$ at $30^{\circ} \mathrm{C}$ and $37^{\circ} \mathrm{C}$ in ghosts from patients compared to $3.76 \pm 0.17$ $\mathrm{pmole} / \mathrm{min} / \mathrm{mg}$ and $5.86 \pm 0.30$ pmole $/ \mathrm{min} / \mathrm{mg}$ in ghosts from controls. The PKase activities of patient ghosts were significantly greater than those of control ghosts at both $30^{\circ} \mathrm{C} \quad(\mathrm{p}<0.01)$ and $37^{\circ} \mathrm{C}$ $(p<0.05)$. As was observed in the case of spectrin phosphorylation, band 3 Pkase activities of patient ghosts were increased identically to $111 \pm 6.1 \%$ of the activities of control ghosts at both temperatures.

The mean phosphorylation of phospholipid was found to be reduced in patient ghosts although the difference was not statistically significant. The rate of phosphorylation of phospholipid in patient ghosts was $10.81 \pm 0.93 \mathrm{pmole} / \mathrm{min} / \mathrm{mg}$ and $9.79 \pm 0.90 \mathrm{pmole} / \mathrm{min} / \mathrm{mg}$ at $30^{\circ} \mathrm{C}$ and $37^{\circ} \mathrm{C}$ respectively compared to $12.84 \pm 2.09 \mathrm{pmole} / \mathrm{min} / \mathrm{mg}$ and 11.33 $\pm 1.65 \mathrm{pmole} / \mathrm{min} / \mathrm{mg}$ in the controls.

\section{TEMPERATURE RESPONSE}

There was no difference between the patients and controls in the change of the three kinase activities in response to the temperature change from $30^{\circ} \mathrm{C}$ to $37^{\circ} \mathrm{C}$. Temperature response of each enzyme activity was assessed by expressing the activity determined at $37^{\circ} \mathrm{C}$ as a percentage of the activity at

*A total of 10 patients were studied. However. ageand sex-matched controls were available for only 8 . Thus, although the activities of the two unmatched patients were comparable to the rest of the patients and included in the means, they could not be included in the paired statistical analysis.

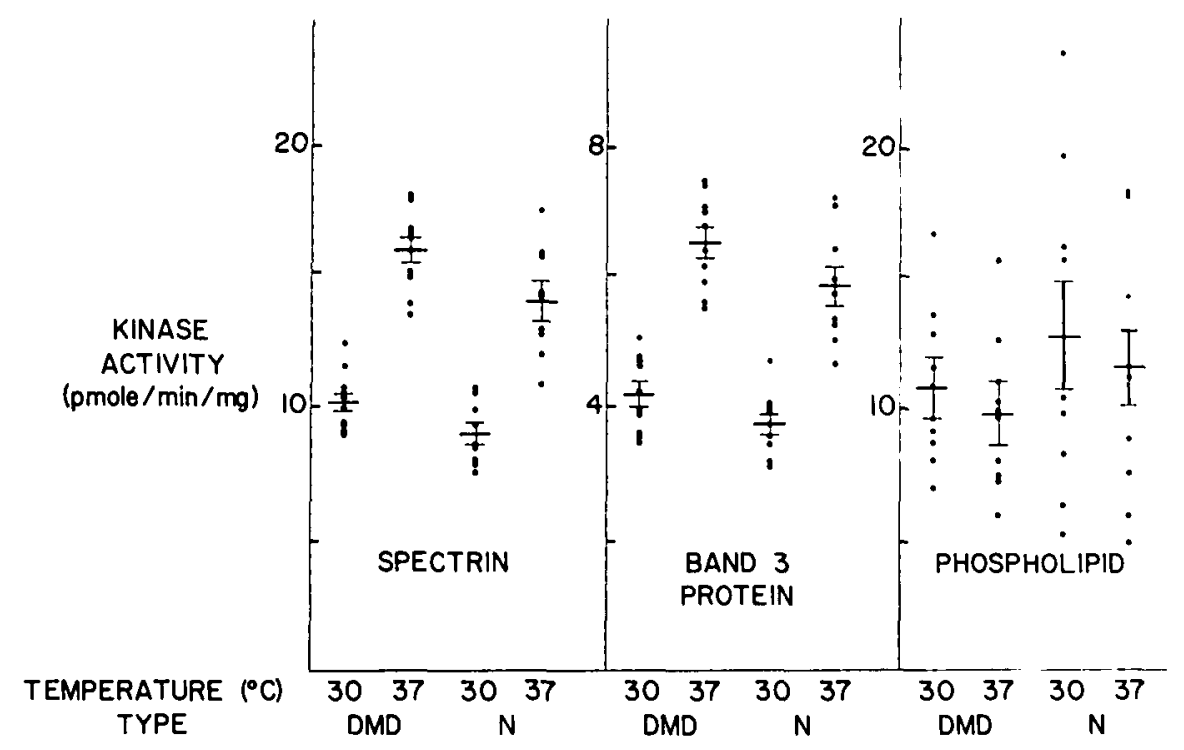

Figure 1-- Comparisons of DMD patient and control erythrocyte ghost kinase activities determined at $30^{\circ} \mathrm{C}$ and $37^{\circ} \mathrm{C}$ with two membrane-bound protein substrates (spectrin and band 3 protein) and phospholipids. The heavy horizontal bar is the mean of a group of samples, the others represent the standard error of the mean difference. Each dot is the mean of duplicate determinations of activity in one individual. $30^{\circ} \mathrm{C}$. Thus the phosphorylation of spectrin in ghosts from patients at $37^{\circ} \mathrm{C}$ is $156.0 \pm 3.9 \%$ of that at $30^{\circ} \mathrm{C}$ while the activity of control ghosts at $37^{\circ} \mathrm{C}$ is $155.9 \pm 4.5 \%$ of that at $30^{\circ} \mathrm{C}$. Similarly, band 3 phosphorylation in ghosts from patients at $37^{\circ} \mathrm{C}$ is $156.2 \pm$ $3.4 \%$ of that at $30^{\circ} \mathrm{C}$ and activity of control ghosts at $37^{\circ} \mathrm{C}$ is $155.8 \pm 3.4 \%$ that at $30^{\circ} \mathrm{C}$.

The temperature response of phosphorylation of the phospholipid fraction is also the same in patients and controls. In both cases the activity at $37^{\circ} \mathrm{C}$ is $90 \pm 3.1 \%$ of the activity at $30^{\circ} \mathrm{C}$.

\section{EFFECT OF AGE ON PKase ACTIVITY}

The effect of age on the protein and phospholipid kinases was examined in a group of 13 normal males (up to 30 years of age), including the 8 controls for the DMD patients. Over this age range, the activity of all three kinases increased with increasing age. Using the least-squares estimate of the relationship between kinase activity and age, the activity was found to increase $49 \%$ for spectrin, $43 \%$ for band 3 and $110 \%$ for phospholipid phosphorylation from 10 years to 30 years. Linear regression analysis showed that the increase in kinase activity was significantly correlated with increasing age $(\mathrm{p}<0.01)$ in all three cases.

MEMBRANE CHOLESTEROL TO TOTAL PHOSPHATE RATIO(C/P ratio)

The cholesterol content of membranes determined as a molar cholesterol to total membrane phosphate ratio was not different between ghosts from patients or controls (Table 1). Furthermore, differences in the PKase activity between the patients and the controls were not correlated with the differences in $C / P$ ratio $(\mathrm{p}>0.2)$.

\section{DISCUSSION}

Our data demonstrate that the rate of phosphorylation of spectrin and band 3 protein is higher in erythrocyte ghosts from patients with Duchenne muscular dystrophy than from normal controls when assayed using optimized incubation conditions. They thus corroborate the reports by Roses et al. 
(1975) and Roses and Appel (1976) which were obtained using less favorable conditions of $\mathrm{pH}$ and temperature.

Since the phosphorylation of both the spectrin and band 3 proteins is altered, any explanation of alterations in the erythrocyte membrane must account for both changes.

Alterations of the amino acid sequence of spectrin or band 3 protein might be suggested to cause the observed changes in the phosphorylation of the other substrate. This effect could be mediated by alteration of the organization or interactions of the proteins in the membrane. However, it seems unlikely that such a change would alter the phosphorylation of both spectrin and band 3 protein to the same extent.

Alternatively, the site of the alteration might be one of the kinase enzymes. However, Roses and Appel (1976) have reported that they find no difference in the ability of PKase extracted from patient ghosts to phosphorylate an exogenous substrate compared to that from control ghosts.

The most likely alternative for a common effector is the lipid component of the membrane, which provides the environment of the enzymes and substrates. The failure to detect any alteration in the membrane lipid organization using physical techniques (Butterfield et al., 1976), which can only detect general changes, does not eliminate the possibility of changes occuring in the lipids immediately associated with the enzymes and/or substrates. These lipids in fact, have been shown to be critical in determining the function of other membrane enzymes (Hesketh et al., 1976; Jain and White, 1977). Other components of the membrane environment, for example, metal ions, might also be altered in quantity, giving rise to the observed changes, although little information is available at present to assess such a possibility.

The phospholipid phosphorylation activities show more variability than do the protein kinase activities. Thus, although the mean activity of phospholipid phosphorylation at both $30^{\circ} \mathrm{C}$ and $37^{\circ} \mathrm{C}$ is less in membranes from patients than from controls, the differences are not statistically significant. One factor that might account for the increased variability of the phospholipid phosphorylation data is that the assay conditions were optimized for the protein phosphorylation reactions and under these conditions the ATP concentration (5 $\mu \mathrm{M}$ ) is not saturating for the phospholipid reaction (Sampara, Vickers and Rathbone, unpublished observations): Therefore, further experiments are required to examine phospholipid phosphorylation under optimal conditions, to determine whether the observed trends represent real differences.

This study confirms the difference reported by Roses et al. (1975) and Roses and Appel (1976) in the rate of phosphorylation of spectrin and band 3 protein in ghosts from patients with DMD and controls. Furthermore, the results show that the elevation of both protein phosphorylations (spectrin and band 3 ) in patients compared to controls are very similar as are the temperature responses. This indicates that the changes of both enzyme activities may be due to the same membrane alteration, with the membrane lipid component being the prime candidate for the site of this alteration although an alteration of a protein (the substrates or Pkases) is not eliminated. This interpretation is in agreement with the hypothesis that there is a general alteration of membrane composition in erythrocytes from patients with DMD. This erythrocyte alteration may then reflect widespread changes in membranes in a variety of tissues and which may account for many or all of the changes observed in muscles or nerves of DMD patients.

\section{ACKNOWLEDGEMENTS}

This research was supported by a Grant-in-Aid from the Medical Research Council of Canada (The MRC Group in Developmental Neurobiology) to A. J. McC. and M.P.R. J.D.V. is a Postdoctoral Fellow of the Muscular Dystrophy Association of Canada.

The authors wish to thank Miss C. Habinski for typing the manuscript and Drs. Brown, Cosmos and Werstiuk for their comments and criticism of the manuscript.

\section{REFERENCES}

APPEL, S. H. and ROSES, A. D. (1976). Membrane biochemical studies in myotonic muscular dystrophy. In: Membranes and Disease, Edit. L. Bolis, J. F. Hoffman and A Leaf. New York: Raven Press. pp 183-195.

ASTER, R. H. and JANDL, J. H. (1964). Platelet sequestration in man. I. Methods J. Clin. Invest. 43, 843-855.

TABLE

Cholesterol to Total Phosphate Ratios of DuD Patients and Controls ( $\mu$ mole cholesterol $/ \mu$ mole ghost phosphate)

\begin{tabular}{|c|c|c|}
\hline & Patient & Control \\
\hline 1 & 0.78 & 0.83 \\
\hline 2 & 0.88 & 0.86 \\
\hline 3 & 0.87 & 0.85 \\
\hline 4 & 0.80 & 0.81 \\
\hline 5 & 0.90 & 0.86 \\
\hline 6 & 0.90 & 0.83 \\
\hline 7 & 0.87 & 0.88 \\
\hline 8 & 0.84 & 0.81 \\
\hline 9 unmatched & 0.81 & \\
\hline 10 patients & 0.84 & \\
\hline
\end{tabular}

\section{Mean C/P Ratio}

\pm standard error of mean

$0.85 \pm 0.01$

$0.84 \pm 0.01$

Paired analysis (on pairs 1 through 8 )

Mean Difference

\pm standard error of mean

p
$0.014 \pm 0.013$

$>0.2$ 
AVRUCH, J. and FAIRBANKS, G. (1974). Phosphorylation of endogenous substrates by erythrocyte membrane protein kinases 1 : A monovalent cation-stimulated reaction. Biochem. 13, 5507-5513.

BIRCHMEIER, W. and SINGER, S. J. (1977). On the mechanism of ATP-induced shape changes in human erythrocyte membranes. II The role of ATP. J. Cell. Biol. 73, 647-659.

BROWN, H. D., CHATTOPADHYAY, S. K. and PATEL, A. B. (1967). Erythrocyte abnormality in human myopathy. Science 157. 1577-1578.

BUTTERFIELD, D. A., CHESTNUT, D. B., APPEL, S. H. and ROSES, A. D. (1976) Spin label study of erythrocyte membrane fluidity in myotonic, and Duchenne muscular dystrophy and congenital myotonia. Nature 263, 159-161.

BUTTERFIELD, D. A. (1977). Electron spin resonance investigations of membrane proteins in erythrocytes in muscle diseases. Biochim. Biophys. Acta 470, I-7.

COLEMAN, R. (1973). Membrane-bound enrymes and membrane ultrastructure. Biochim. Biophys. Acta 300, 1-30.

DHALLA, N. S., MCNAMARA, D, B., BALASUBRAMANIAN, V.. GREENLAW, R. and TUCKER. F. R. (1973). Alterations in adenosine triphosphatase activities in dystrophic muscle sarcolemma. Res. Comm. Path. Pharmacol, 6. 643-650.

DE KRUYFF, B., VAN DIJCK, P. W. M. GOL.DBACH, R. W., DFMEL, R. A. and VAN DEENAN, L. L. M. (1973). Influence of fatty acid and sterol composition on the lipid phase transition and activity of membrane-bound enzymes in Acholeplasma laidawii. Biochim. Biophys. Acta 330, 269. 282.

EDWARDS, A. L. (1976). An Introduction to Linear Regression and Correlation. San Francisco: W. H. Freeman.

ENGEL., W. K. (1974). The vascular hypothesis. In: Recent Advances in Myology: Proc. 3rd Internat. Congr. on Muscle Disease. Edit. W. G. Bradley, D. Gardner-Medwin and J. N. Walton. Amsterdam, Elseivier. p. 166.

EVANS. E. A. and LaCEI.LE. D. L. (1975). Intrinsic material properties of the erythrocyte membrane indicated by mechanical analysis of deformation. Blood 45, 29.

FAIRBANKS, G.. STECK, T. 1. and WALI.ACH, D. F. H. (1971). Electrophoretic analysis of the major polyeptides of the human erythrocyte membrane. Biochem. 10, 2606-2617

FARIAS, R. N., BI.O.I, B., MORERO, R. D., SINERIZ. F. and TRUCCO, R. E. (1973), Regulation of allosteric membrane-bound enrymes through changes in membrane lipid composition. Biochim. Biophys. Acta 415 . 231-251.

HESKEIH. T. R.. SMITH. G. A.. HOUSLAY, M. D.. McGIl.I. K. A.. BIRIDSALL. N. J. M., METCAIFE, J.C. and WARREN, G. B. (1976). Annular lipids determine the AlP-ase activity of a calcium transport protein complexed with dipalmitoyllecithin. Biochem. 15, 4145-4151.
hODSON, A. and Pleasure, D. (1977). Erythrocyte cation-activated adenosine triphosphatases in Duchenne muscular dyst rophy. J. Neurol. Sci. 32, 361-369.

HOSEY, M. M. and TAO, M. (1977). Protein kinases and membrane phosphorylation. In: Current Topics in Membrane Research. Edit. F. Bronner and A. Kleinzeller. New York: Academic Press, pp. 265-266.

HOWLAND, J. L. and IYER, S. L. (1977). Erythrocyte lipids and heterozygous carriers of Duchenne muscular dystrophy. Science 198, 309-310.

IYER, S. L.. KATYARA, S. S. and HOWLAND, J. L. (1976). Elevated erythrocyte phosphorylation associated with Duchenne and myotonic muscular dystrophy. Neurosci. Letters 2. 103-106.

JAIN, M. K. and WHITE, H. B. (1977). Long range order in biomembranes. In: Advances in Lipid Research, Vol. 15. Edit. R. Paoletti and D. Kritchevsky. New York: Academic Press, pp $|-6|$.

KALOFOUTIS, A., JULLIEN, G. and SPANOS, V. (1967). Erythrocyte phospholipids in Duchenne muscular dystrophy. Clin. Chim. Acta 74, 85-87.

KIMELBERG, H. K. (1975). Alterations in phospholipid-dependent $\left(\mathrm{Na}^{+}+\mathrm{K}^{+}\right)$ATPase activity due to lipid fluidity. Effects of cholesterol and $\mathrm{Mg}^{2+}$.Biochim. Biophys. Acta 413, 143-156.

KREINER, P. W., KEIRNS, J. J. and BITENSKY. M. W. (1973). A temperaturesensitive change in the energy of activation of hormone-stimulated hepatic adenyl cyclase. Proc. Nat. Acad. Sci. USA 70, 17851789.

KUMAMOTO, J., RAISON, J. K. and LYONS, J. M. (197I). Temperature "breaks" in Arrhenius plots: A thermodynamic consequence of a phase change. J. Theor. Biol. 31. 47-51.

KUNZE, D., REICHMANN, G.. EGGER, E., LEUSCHNER, G. and ECKHARDT, $H$. (1973). Erythrozytenlipide bei progressiver muskeldystrophie. Clin. Chim. Acta 43, 333341.

LOWRY, O. H., ROSEBROUGH, N. J.. FARR, A. L., and RANDALL. R. J. (1951). Protein measurements with the Folin phenol reagent. J. Biol. Chem. 193: 265-269.

MAWATARI, S., TAKAGI. A. and ROWLAND, L. P. (1974). Adenyl cyclase in normal and pathologic human muscle. Arch. Neurol. 30. 96-102.

MAWATARI, S.. MIRANDA. A. and ROWLAND. L. P. (1976). Adenyl cyclase abnormality in Duchenne muscular dystrophy: Muscle cells in culture. Neurol. 26. 1021-1026

MAWATARI, S., SCHONBERG, M. and OLARTE. K. (1976). Biochemical abnormalities of erythrocyte membranes in Duchenne dystrophy. Arch. Neurol. 33.489493.

McCOMAS, A. J., SICA, R., and CAM PBELL. J. J. (1971). Sick motoneurones. A unifying concept of muscle disease. Lancet 1: 321-326.
McCOMAS, A. J. (1977). Neurological Function and Disorders, Butterworth. l.ondon.

MISSIRLIS, Y. F., KOHN, I. L.., VICKERS, J. D. RATHBONE. M. P.. (HUII, D. H. K.. MCCOMAS, A. J., and BRAIN, M. C. (1977). Alterations in erythrocyte membrane material properties: A marker of the abnormality in human and chicken muscular dystrophy. In: Proc. 4th Internat. Conf. on Red Cell Metabolism and Function (in press).

NIEBROJ-DOBOSZ, I. (1976). Erythrocyte ghosts $\left(\mathrm{Na}^{+}+\mathrm{K}^{+}\right)$ATPase activity in Duchenne's dystrophy and myotonia. J. Neurol. 214, 61-69.

PERCY, A. K. and MILL.ER. M. E. (1975). Reduced deformability of erythrocyte membranes from patients with Duchenne muscular dystrophy. Nature 258. 147-148.

PETER, J. B., WORSFOI.D. M. and PEARSON, C. M. (1969). Erythrocytc ghost adenosine triphosphatase (ATPase) in Duchenne dystrophy. J. L.ab. Clin. Med. 74. 103-108.

PINDER, J. C., BRAY, D. and GRATZER, W. B. (1977). Control of interaction of spectrin and actin by phosphorylation. Nature 270, 752-754.

PUCHWEIN. G., PFEUFFER, T. and HEL.MREICH. E. J. M. (1974). Uncoupling of catecholamine activation of pigeon erythrocyte membrane adenylate cyclase by filipin. $J$. Biol. Chem. 249. 3232-3240.

RAISON, J. K.. LYONS, J. M., MEHLHORN, $R$. J, and KEITH, A. D. (1971). Temperature-induced PKase changes in mitochondrial membranes detected by spin labelling. J. Biol. Chem. 246, 4036-4040.

ROSES, A. D. and APPEL. S. H. (1976). Erythrocyte spectrin peak Il phosphorylation in Duchenne muscular dystrophy. $J$. Neurol. Sci. 29. 185-193.

ROSES, A. D., HERBSTREITH. M. H. and APPEL. S. H. (1975). Membrane protein kinase alteration in Duchenne muscular dystrophy. Nature 254, 350-351.

ROSES, A. D.. ROSES, M. J., MIL.L.ER. S. E., HULL, K. L. Jr. and APPEL., S. H. (1976a). Carrier detection in Duchenne muscular dystrophy. New Eng. J. Med. 294. 193-198.

ROSES, A. D., HERBSTRETTH, M., MFTCALF. B. and APPEL. S. H. (1976b). Increased phosphorylated components of erythrocyte membrane spectrin band II with reference to Duchente muscular dy'strophy. J. Neurol. Sci. 30, 167-178.

RUNYON. R. P. and HABER. A. (1972). Fundamentals of Behavioural Statistics. 2nd Edition. Menlo Park. California: AddisonWesley Publishing Co., pp 204-209.

SHA AFI, R. I., RODAN.S. B., HINTZ., R. 1... FERNANDEZ, S. M. and RODAN, G. A. (1975). Abnormalities in membranc microviscosity and ion transport in genetic muscular dystrophy. Nature 254. 525-526.

SHEETZ, M. P. and SINGER. S. J. (1977). On the mechanism of ATP-induced shape changes in human erythrocyte membranes. 1. The role of the spectrin complex. J. Cell. Biol. 73, 6.38-646. 
STEWART, P. A., WERSTIUK, E. S., VICKERS, J. D. and RATHBONE, M. P. (1977). Elevated cholesterol levels in tissues of chicken embryos with hereditary myotonic muscular dystrophy. Exptl. Neurol. 57, 475-485.

VICKERS, J. D. and RATHBONE, M. P. (1977). Effect of erythrocyte membrane cholesterol on a membrane protein kinase activity. In: Proc. 20th Ann. Mtg. Canadian Fed. Biol. Soc. pp 65.
WARREN, G. B., HOUSLEY, M. D., METCALF, J. C. and BIRDSALL, N. J. M. (1975). Cholesterol is excluded from the phospholipid annulus surrounding an active calcium transport protein. Nature 255, 684687.

WEBER, K. and OSBORN, M. (1969). The reliability of molecular weight determinations by dodecyl sulfate-polyacrylamide gel electrophoresis. J. Biol. Chem. 244, 44064412. 